\title{
Study of Gender in Adaptation Strategies Post Kelud Volcano Eruption 2014
}

\author{
A. Purnomo \\ Fakultas Ilmu Sosial \\ Universitas Negeri Malang \\ Malang, INDONESIA \\ purnomo.agus88@gmail.com
}

\begin{abstract}
Kelud Volcano eruption in 2014 has weakened every aspects of life in society are affected. In the village of Pandansari Ngantang Malang, most of the people are farmers. 90\% of work people are farmers and farm workers (mreman). So that when the disaster happens they do not have a livelihood again. This study used a qualitative approach with a focuson assessing the impact of catastrophic eruptions for the life ofthe community, especially for women and strategy of sustainable livelihoods of households. The research subjects as many as 90 people were taken from the $15 \%$ of families who work in the agricultural sector with interactive model developed by Miles and Huberman. Women in disasters can have a big impact in accelerating the recovery efforts after the disaster. Adaptation strategies undertaken by women include social and economic adaptation. The forms of adaptation do not necessarily carried out by all the village women Pandansari, it is influenced by several factors, such as level of education and the number of members of the family.
\end{abstract}

Keywords: livelihood, adaptation strategies, and the role of women

\section{INTRODUCTION}

Region of the earth's surface has different vulnerabilities. Indonesia is a region with a high risk of geological disasters, this is because the position at the confluence of three tectonic plates. These conditions resulted in ocean trenches and volcanic row that extends parallel to the shoreline. The number of volcanoes in Indonesia has positive and negative effects, its positive impact is fertile land for agriculture and the negative impact is primary or secondary disaster of the volcano.

One of these important variables that must be taken into account is that a similar disaster could bring different impacts for different gender groups. Like flood or earthquake, for example, the impact for men and women are not identical, one of which is caused by differences in vulnerability to disasters due to existing gender relations. UNDP report (2010) states that (1) in a disaster female life expectancy is lower than in men, the data from 141 countries in the period between 1981 - 2002 and (2) women and children at risk 14 times more vulnerable in the event of a disaster than in men.

Gokhale (2008) revealed when the earthquake occurred in the Indian women will feel the social impact is more severe than in men. Existing inequalities root causes of disaster vulnerability in women. These inequalities result in any disaster that occurs will impact differently on women/children and men (Bradshaw and Fordham. 2013).

Elaine (1997) explains that the risk to disasters differently distributed in the community. According to him, as a complex concept, the vulnerability is influenced by many factors. One of them is the difference in access to and control over resources, which are needed both for survival and undergo a period of recovery after a disaster. However, he underlined that women and girls are part of a group of people who are on the list of high-risk groups to disasters (Elaine. 1997)

Kelud Volcano aftermath of natural disasters in 2014, many villagers Pandansari activities Ngantang which has constrained agricultural production and crop failure. Kelud eruption causing damage to the physical, social and economic environment as well. In disasters, women and men often lose the capacity to sustain the livelihoods of their families due to loss of income sources/resources production (Murtakhamah. 2013).

The incident makes all citizens must work hard in the reconstruction and rehabilitation after the disaster occurred. Lost most of his possessions to make all family members to work hard in the process of rehabilitation and reconstruction. But usually it results in changes in gender roles (women and men). The workload of women often increases after a disaster (Hidayati, et al. 2012).

This issue can not be separated from the issue of culture. When a person grows they adopt gender roles covering how men and women should think, act and feel according to the demands of culture (Crawford and Unger. 2000). Therefore gender roles are roles expected by culture against men or women in the face of disaster.

On the basis of this fact, the focus of this study was Assessing the economic livelihood strategies of farm households villagers Pandansari Ngantang as a form of adaptation to the women after the eruption of Volcano Kelud 2014.

\section{RESEARCH METHODS}

This reaseacrh is seeks to assess the impact of disasters kelud eruption for village life Pandansari Ngantang especially for women and the livelihood strategies of sustainable household villagers Pandansari after the eruption of Volcano Kelud 2014. This study used 
a qualitative descriptive method. From the secondary data processing Malang in Figures, the total number of population is 603 respondents (household farmers), the determination of sample respondents who will be the informant as much as $15 \%$. This refers to the opinion of Sugiono (2008) which states that if a population of more than 100 , it can be as much as $10-30 \%$ of samples. So the number of informants in this study was 90 . The data analysis was prepared by adopting Qualitative data analysis techniques developed by Miles and Huberman (1992) ie interactive model analysis.

\section{RESULT}

Most of the villagers Pandansari working in the agricultural sector with superior products such as rice. In order to boost economic activities, the district government seeks to maximize the potential that exists as the maintenance of dairy cows, considering the number of land around the forest that can be used for planting grass/kolonjono very good for animal feed dairy cows, resulting in increased milk production can continue.

Based on the map Disaster Prone Areas (KRB) Kelud made by the Centre for Volcanology and Geological Hazard Mitigation (PVMBG) in 2014, Pandansari village lies in the KRB II and I.

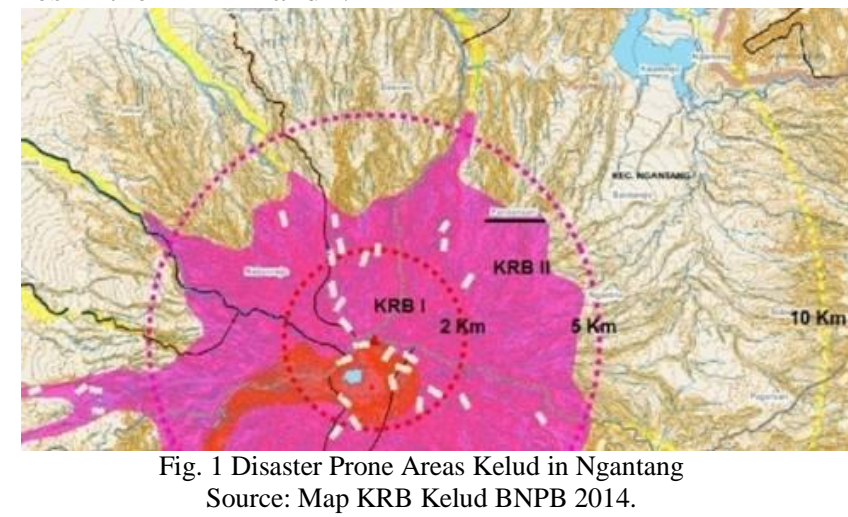

In the phase of pre-eruptive volcano Kelud 2014, Pandansari village livelihood strategies Ngantang Malang District did not experience significant disruption on human assets, natural, physical, financial, and social. Based on interviews with the residents, they have no idea if the impact of the volcanic eruption of Kelud will be very severe. Before the 2014 eruption, volcanic ash and/or material eruption never get to the district of Malang.

\footnotetext{
"meterial not have thought up here, because the first-former was never hit. The eruption in 1966 only ash, eruption in 1990 here is safe, do not hit, yesterday that 2007 will erupt but actually not so, well then this new 2014 knew the wind direction here. Material up to the village, a new person to flee. When the improvement of the status at 21:00 PM, people are still waiting and watching."'(Villagers Pandansari ${ }^{1}$ )
}

From the description it can be concluded that the village Pandansari never affected by the volcanic eruption of Kelud directly resulting in severe damage. They also do not make preparations to evacuate because of the previous disaster (2007) Volcano Kelud does not erupt. So when an

1 Villagers interviewed named Sumiati (60) who have experienced severe Kelud Volcano eruption in 1990 but the worst affected areas at the time was Blitar. Pandansari village increase in the status of being alert to erupt many people panic and do not know what to do.

Head of Village Munjung Pandansari explained that only one citizen who died shortly after the eruption. The death toll was 80 years old and suffered from respiratory problems that can not be helped. While interviews with some of the residents showed that the pain suffered after the eruption had little impact, and can be directly cured.

The age group also determine the level of vulnerability and changes in these assets. In the age group of children and teenagers who are schools have severe psychological trauma. Some children still experience fear until 3 months after the eruption, and some schools are reluctant teenagers to school for several months because of the same thing. Plus access to schools damaged by the brunt of cold lava to go to school so they need to cross the river at any time of cold lava can occur during the rainy season. So some children still had to be delivered to school by their parents.

Total agricultural activity was also suspended after the eruption. This is because agricultural land entirely covered by the eruption of material in the form of volcanic ash and rock pumice. According to the residents, to returns the agricultural land to be planted back as they take several weeks to more than 1 year. Because until now there are some farms that can not be replanted. According to residents affected land hot ash has properties that seed planted will die. So since it is a few people decided to become a sand miner for a while until the land can be replanted.

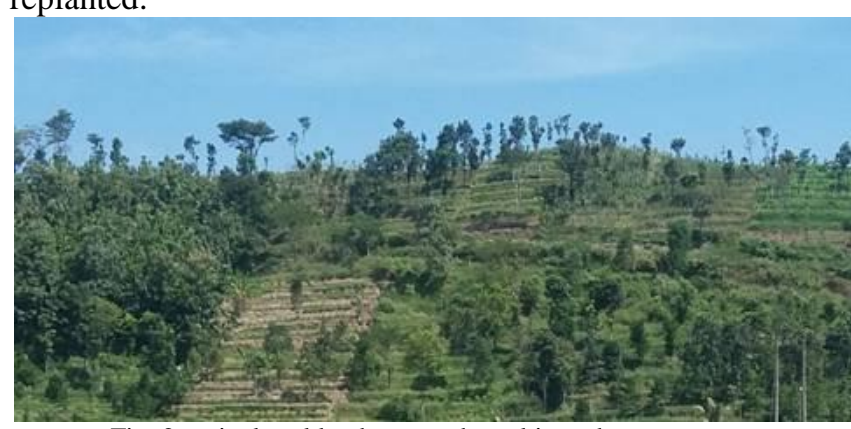

Fig. 2 agricultural land can not be cultivated up to now Source: Primary Data, 2015

There is no agricultural land that can be harvested. even some farmers suffered losses of up to Rp. 200 million because of the loss of arable land and into rivers. While most farmers experienced kerungian between Rp. 5,000,000 to Rp. 25,000,000 due to loss of seeds and can not grow for some time.residents who did not have arable land and worked as a laborer/mreman reported experiencing losses of between Rp. 1,000,000 to Rp. 5,000,000 due to lose their jobs for a while.

But most people do not feel a loss of their jobs sector as farmers. This is because their crops of rice just for their own consumption. And when the eruption occurred in the form of food assistance came pouring so thought lost property derived from agricultural products there instead. From interviews help continues to flow until 3

just happened ash and not as severe eruption that occurred in 2014. In the 2007 eruption dampakya not at all perceived by villagers Pandansari. 
months after the eruption. Assistance in the form of clean water, foodstuffs and building materials.

In the post-eruption phase, the population livelihood of farmers still do not have the capital to be able to start activity again. Livestock farmers who survived during the post-eruption had difficulty in finding the animal feed because of volcanic ash and pumice turn off all the existing vegetation. So therefore the citizens that the cattle could be saved choose to sell cattle as initial capital business. But the destruction of agricultural land resulting in many farmers who need additional capital to restore their land. On the basis that not a few farmers who choose to move into the sand diggers while waiting for the land to recover.

Assistance in the phase of post-eruption continued to arrive. Residents who have had a previous loan to the bank granted low-interest working capital assistance for free to start their business back. Farmers also receive assistance in the form of seeds and medicines. From local governments and animal husbandry department to provide assistance in the form of a productive dairy cattle breeders.

The main damage to the building located on the roof of a house destroyed by a burst of volcanic material. Many residents do not have time to save property so most of the furniture and the furniture badly damaged. Based on interviews with informants, they are not expected to be as severe eruption that and just to secure items such as furniture under the mattress. Apparently after 4 days to evacuate and are allowed home they find the house had been flattened.

The rehabilitation and reconstruction of houses initially progresses slowly and seem like more citizens waiting for help from the military and volunteers. In addition to the constraints derived from the main access into the village Pandansari interrupted because of cold lava, residents claimed was still traumatized and less prepared for the eruption of Volcano Kelud 2014.

Current eruption phase relationships between citizens increasingly interwoven. Tradition of mutual assistance to clean and repair the houses done together. Renofation done rotating from house to house in accordance with a predetermined order. Each house to get their turn to be repaired and get urgent assistance in accordance with the needs of home improvement mereka.Warga also respond well to any aid that comes to the village Pandansari. Residents do not feel disturbed by the residents from outside the village who came just to watch, because they only watch on the village boundary. Residents outside who come to watch keen on cold lava flow that suddenly formed and cut off access into the village. So indirectly the difficulty of access to the village to make unauthorized residents outside can not enter.

\section{DISCUSSION}

Women constitute one of the most important actors in the process of reconstruction and rehabilitation after the disaster, but in some aspects of the study or in programs after the disaster they are not adequately

2 Isah (31) is an immigrant population that is married with villagers Pandansari and already has one child who is in grade 2 elementary school. His educational background is in high involved. These conditions have been regarded as commonplace as in Javanese culture, women have long been constructed socially and culturally to be "kanca wingking" (Women constructed just well on a variety of domestic affairs and its movement is limited within the scope of the household) (Nugraheni $\mathrm{S}$. 2012). They are generally seen as passive victims in postdisaster programs. In fact, women have an important role in regulating the economy or making a family make important decisions. One informant $\left(\mathrm{Isah}^{2}, 31\right)$ provide information to ask her husband to go abroad as migrant workers after post Kelud Volcano eruption in 2014 occurred. Isah concept as kanca wingking have a domestic role to perform its functions to regulate in the house. Isah husband while a kanca ngajeng which has a public role whose role is to meet all the needs and domestic purposes. As proposed by Koentjoro that the couple often referred to garwa is the acronym of sigaraning nyawa (soul mate), each of which has the role of domestic and public, the wife as kanca wingking have domestic roles and husband as kanca ngajeng has a public role ,

Deny the fact that women are passive victims. One of the evidence indicates otherwise. Women can perform its role as usually even more than men in some cases after the disaster showed that violent stance and tends to craze (Chew and Ramdas. 2005). Some interviews show there are housewives who make the decision to sell their livestock in order to be used as working capital or ask the husband to work on the excavation of sand for a while. They have thought that the land affected by the eruption of Volcano Kelud will take a long time and cost a bit to be replanted. Besides assistance from the government was limited to the provision of seeds and cows for groups of farmers, but there is no attempt to recover arable land so that there are some farmers who do not have the capital were forced to leave their land fallow temporarily and work in other sectors.

The strategy of adaptation is done every woman is different. As for some of these strategies is to allocate a social strategy that includes the entire family to work and increase family income. As is done in Mrs Rusiatin (42) who have family members as much as 4 people. Before the eruption of 4 family members who are still dependent not work, they only occasionally came to help paddy when the harvest comes. But in the post-eruptive phase She invite all members of the family to be a farmhand/mreman who wages a day could reach Rp. 25,000 if they work full all day from morning till noon. So if earlier when the family was only earning an average of Rp. 50,000 per day now with the addition of 4 people this family workers earn an additional income of Rp. 100,000 per day. With the addition of this pengahasilan family economy is expected to recover quickly.

As reported by Tobin (2001) which explains that there is equality of roles between women and men, are now both looking for income and jointly take care of the household. This fact reinforces the opinion Hidayati (2012) that women have more burden of having to run two roles at once. So the disaster provides an opportunity to

school. For reasons do not have arable land Isah then asked her husband to go abroad as migrant workers to supplement the family income. 
change the role of women and their status in society (Thurairajah).

But not all residents of the village Pandansari implement social adaptation strategies that allocates all family members to work. Mrs Sumiati (60) who have family members as much as 3 people do not do that. The reason they are fresh out of school and still traumatized so that when they are working still like the confusion.

Social adaptation strategies are also done regularly hold activities together citizens who routinely done every week. From the results of the survey and interview these activities in the form of tahlil and PKK. This activity is an activity that is already routinely done long before the eruption occurred. But the post-eruption phase, the head of the village argued if these activities need to continue to be held in order to provide citizens of the post-eruption activities as well as to restore the conditions of the new psychological trauma. Call (2012) argued in Indonesian society there is a belief that by increasing the levels of religiosity will reduce the risk of disaster in the future.

Economic adaptation strategies undertaken by village women Pandansari include diversification of work. Some women decide that her husband worked in different sectors during the wait farmland can be replanted. These sectors are mining (sand quarrying), construction (construction workers), and industrial (factory workers). The mining sector is the sector most. Most of the farmers who lost their land because of the cold lava flood Konto River turning into sand miners. Some sand miners working on the basis of recommendation of his wife and others are selfconsciousness for a living quickly. Farmers working in the mining of sand claimed to have fee enough for everyday life. Income from mining sand obtained by collecting 1 sand truck (1 rit) which is the equivalent of 6-8 cubic, either alone or in groups. The results are then sold and divided equally in accordance with the number of miners. Price 1 truck of sand can reach Rp. 250,000 to 300,000 .

\section{CONCLUSION}

Adaptation strategies undertaken by women after the eruption of Volcano Village Pandansari Kelud 2014 include economic and social adaptation. On social adaptation few women allocate all family members to work, another form of adaptation is with the activities of gathering people who routinely done once a week. And on the adaptation of the economy, some women apply diversification work to increase the family income while waiting for agricultural land can be reprocessed. The whole form of adaptation is an attempt to restore livelihoods quickly. The forms of adaptation do not necessarily carried out by all the village women Pandansari, it is influenced by several factors, such as level of education and the number of members of the family

\section{REFERENCES:}

[1] Bradshaw, Sarah and Fordham, Maureen. 2013. WOMEN, GIRLS AND DISASTERS A review for DFID.Northumbria University and Gender and Disaster Network www.gdnonline.org

[2] Call, Caleb M. 2012. Viewing a world of disaster through the eyes offaith: The influence of religious worldviews oncommunity adaptation in the context of disaster related vulnerability in Indonesia. Iowa State University
[3] Chew, L. dan K. N. Ramdas. 2005. Caught in the Storm: The Impact of Natural Disasters on Women.The Global Fund for Women.

[4] Crawford, M and Unger, R. 2000. Women and Gender. McGraw Hill: New York

[5] Elaine Enarson. 1997. Gender Equality, Work, and Disaster Reduction: Making the Connection. ILO

[6] Enarson. 2000. Women's Voluntary Work Expands : Gender Equality, Work and Disaster Reduction : Making The Connection. revised version of Gender and Natural Disasters, Working Paper \# 1 (September, 2000) prepared for the ILO In Focus Programme on Crisis Response and Reconstruction. Correspondence to E. Enarson (eenarson@earthlink.net), 33174 Bergen Mt. Rd., Evergreen, CO, 80439, USA.

[7] Gokhale, Vasudha (2008). Role of Women in Disaster Management : An Analytical Study with Reference to Indian Society. artikel dipublikasikan dalam The 14th World Conference on Earthquake Engineering 12-17 Oktober - Beijing, China.

[8] Hidayati, Deny. 2012. Pengelolaan Bencana Berbasis Gender: Pembelajaran dari gempa Bantul 2006. PT Dian Rakyat

[9] Koentjoro, dkk. Tanpa Tahun. Disaster, Gender, and Poverty. Universitas Gadjah Mada - Fakultas Psikologi

[10] Miles, M.B., \& Huberman, A.M. 1992. Qualitative Data Analysis: an Expanded Source Book. Thousant Oaks CA: Sage Publication Inc.

[11] Murtakhammah, Titin. 2013. Pentingnya Pengarustamaan Gender dalam Program pengurangan Resiko Bencana. WALFARE, Jurnal Ilmu Kesejahteraan Sosial, Vol. 2, No. 1 Tahun 2013

[12] Nugraheni S, Wahyu. 2012. Peran dan Potensi Wanita dalam Pemenuhan Kebutuhan Ekonomi Keluarga Nelayan. Journal of Educational Sosial Studies (JESS) Vol. 1, No. 2: 104-111

[13] Sugiyono. 2009. Metode Penelitian Kuantitatif, Kualitatif, Dan R\&D. Bandung: CV Alfabeta

[14] Tobin, Graham A. 2001. The Role of Women in Post-Disaster Environments: Health and Community Sustainability - Final technical Report for The Center for Disaster Management and Humanitarian Assistance.

[15] Thurairajah, Nirooja. Tanpa Tahun Terbit. Post disaster reconstruction as an opportunity for development: women's perspective. Research Institute for the Built and Human Environment: University of Salford.

16] UNDP. 2010. Disaster Risk Reduction 